\title{
Osaamisesta ja oppimisesta muuttuvissa toiminta- ja työympäristöissä
}

Pekka Ruohotie (2000) Oppiminen ja ammatillinen kasvu. $326 \mathrm{~s}$. WSOY

Yhä laajemmin on alettu vakuuttua siitä, että uuden teollisen vallankumouksen aikakausi on todellisuutta uuden vuosisadan alkaessa.

Muutosvoimana on erityisesti uusi informaatio- ja kommunikaatioteknologia ja Internet, jotka mullistavat myös yritystoimintaa, työn luonnetta, markkinointia ja oppimisen käytäntöjä. Oppimisesta on tullut elinikäistä sekä ammatillisen kasvun, johtamisen että informaatiohallinnan aloilla. Tämä on havaittu niin yrityksissä, järjestöissä kuin koulutusta antavissa oppilaitoksissakin.

Professori Pekka Ruohotien teos "Oppiminen ja ammatillinen kasvu" on erinomainen suomenkielinen perusjohdatus osaamisen ja oppimisen problematiikkaan uusimman tutkimustiedon pohjalta muuttuneitten olosuhteitten edellyttämässä työelämässä. Tekijä pyrkii kirjassaan vastaamaan mm. kysymyksiin siitä, millaisia pätevyysvaatimuksia jatkuvasti muuttuva toimintaympäristö asettaa nykyajan ihmiselle ja miten ammatillista kasvua voidaan tukea. Hän myös pohtii jatkuvan oppimisen vaatimusta ja yhteistoimintaan kykenevän tiimin muodostumista sekä esimiehen roolia. Karkeasti yleistäen kirja jakautuu aikuisoppimisen teoreettisia perusteita käsittelevään osaan sekä oppimista työelämän organisaatioiden kontekstissa käsitteleviin lukuihin.

Ruohotie toteaa kirjansa alussa, että "ihmiset, jotka ovat sitoutuneet jatkuvaan oppimiseen, ovat koko ajan avoimia uudelle informaatiolle ja pyrkivät ajoissa ennakoiden välttämään osaamisaukkoja." Tämä erinomainen oivallus sopii koko kirjan motoksi, kun tekijä vielä toteaa johdannossaan, että uutta teknologiaa hyödyntämällä yksilöt ja organisaatiot voivat tunnistaa osaamiskuiluja, paikantaa ne osaamisalueet, joita tulee kehittää. Näihin asioihin kirjoittaja johdattelee lukijaansa muuttuvaa työelämää koskevassa johdantoluvussaan.

\section{Nopeat ja yllättävät} muutokset ovatkin lähes ainoita pysyvyyksiä epävarmuuden hallitsemassa maailmassa. Ruohotie käy yksityiskohtaisesti läpi tunnettuja tietoyhteiskunnan paradokseja, joihin mm. kuuluu tiedon panttaaminen ja salailu tiedon markkina-arvon ylläpitämiseksi. Informaatiotutkija olisi kenties pohtinut tätä paradoksia enemmänkin, sillä kun yhä merkittävämmäksi muodostuva immateriaalinen arvo "informaatio" on luonteeltaan synergistä eli sellaista, että mitä enemmän sitä antaa ja jakaa, sitä enemmän informaatiota saa. Päinvastaisessa tapauksessa eli panttaamisessa huomaakin äkkiä, että infor- maatio ei kehity ja osoittautuukin nopeasti vanhentuneeksi.

\section{Kirja esittelee} ansiokkaasti vanhaa ja uutta näkemystä motivaatiosta, työn rakenteesta ja vastuusta. Samoin siinä kuvataan yleisten työelämävaatimusten ja kompetenssien ulottuvuuksia, joihin kuuluvat elämänhallinta, kommunikointitaito, ihmisten ja tehtävien johtaminen, sekä innovaatioiden ja muutosten vauhdittaminen. Juuri näillä alueilla tapahtuu perinpohjaisia muutoksia.

\section{Esimerkiksi kommuni-} kointitaito on laajentunut yritysten kehitysstrategioissa mediakompetenssiksi, joka on koko tietoyhteiskuntakehityksen perusvaatimuksia. Esimerkiksi saksalainen Bertelsmann Stiftung tunnistaa periaatteissaan "Kommunikationsordnung 2000" media ja viestintäalan kasvavan merkityksen koko kansantaloudelle ja määrittelee mediakompetenssin tietoyhteiskunnan perusvaatimukseksi. Siihen kuuluu säätiön strategiapaperin mukaan ennen kaikkea ongelmanratkaisukyky, teknisen ja sisällöllisen informaatiohallinnan tietotaito sekä kyky informaation kriittiseen arviointiin ja sen esittämiseen.

Verkottuva talous- ja yritystoiminta, koulutus ja työ edellyttävät uusia taitoja etäläsnäolon, vuorovaikutuksen ja digitaalisen lukutaidon hallitsemiseksi. Myös johtami- 
sen viestintä muuttuu siten, että aidon vuorovaikutuksen taidot sekä monikulttuurinen osaaminen muodostuvat välttämättömiksi. Ammatillisen kasvun edellytyksiä pohtiessaan Ruohotie erittelee mm. oppimiskulttuurin kehittymistä ja oppivan organisaation kehittämisstrategioita.

\section{Aikuisoppimisen teoriaa}

Ruohotie erittelee luvuissa, joissa käsitellään mm. motivaatiota, tahtoa ja oppimista, aikuisen oppimista, kokemuksesta oppimista, itseohjautuvuutta ja itsesäätelyä, sekä uudistavaa oppimista. Monet peruskäsitteet on arvioitava perusteellisten muutosten olosuhteissa. Esimerkiksi motivaatio on yritysmaailmassa perustunut tähän saakka paljolti kilpailuasenteeseen, mutta tulevaisuudessa sen lähtökohtana saattaa olla tarve rakentaa uutta. Siksi on hyvä tutustua eri teorioihin motivaatiosta ja oppimishalusta.

Oppimiserojen ymmärtämiseksi kirjassa esitetään selkeästi kognitiiviset, affektiiviset ja konatiiviset rakenteet. Siinä esitetään myös nk. ARCS-malli opetuksen suunnittelemiseksi. Mallin keskeisiä osa-alueita ovat tarkkaavaisuus, relevanssi, itseluottamus ja tyytyväisyys.

\section{Teoreettisiin perusteisiin} kuuluu myös kirjan luku erilaisista orientaatioista aikuisen oppimiseen. Näitä ovat behavioristinen, kognitiivinen, humanistinen ja sosiaalisen oppimisen suuntaus sekä tällä hetkellä laajalti suosittu konstruktivismi. Kuten esimerkiksi intialais-amerikkalainen professori K.S. Sitaram on osoittanut, samoja suuntauk- sia esiintyy esimerkiksi kulttuurin ja viestinnän keskinäisiä suhteita tutkivassa kirjallisuudessa esimerkiksi kysymyksessä siitä, onko kommunikaatiokyky ja henkinen mielentila opittavissa viestintätekniikoita käyttämällä (behavioristit) vai olisiko viestintätekniikoihin sisällytettävä myös ei-verbaalisia, paralingvistisiä mediasanomia ja mielentilan kehityttävä sisältäpäin (humanistinen suuntaus). Ruohotien kirjassa on selkeästi esitetty taulukko näiden viiden ppimisorientaatioiden ominaisuuksista (s.124).

\section{Behavioristit määrittelevät} oppimisen käyttäytymisen muutokseksi. Oppimista voidaan sen ajattelutavan mukaan arvioida ulkoisen käyttäytymisen perusteella mittaamalla yksilön reaktioita ärsykeympäristössä. Kognitiivinen orientaatio taas keskittyy sisäisiin henkisiin prosesseihin. Tämän ajattelutavan edustajat ovat kiinnostuneita ulkoisten ärsykkeiden havainnoimisesta ja tulkinnasta eli siitä, kuinka tietoa prosessoidaan, varastoidaan ja palautetaan mieleen.

\section{Humanistinen orientaatio} korostaa inhimillisyyttä, henkistä potentiaalia ja emootiota. Oppiminen on sen mukaan muutakin kuin kognitiivisia prosesseja ja avointa käyttäytymistä. Sosiaalisen oppimisen orientaatio puolestaan korostaa sosiaalista ympäristöä, jossa oppiminen tapahpahtuu. Ihmisen observointi tietyssä ympäristökontekstissa on tärkeää, koska oppimista voidaan ymmärtää vain tarkkailemalla yksilön, ympäristön ja käyttäytymisen vuorovaikutusta.
Kiintoisa on Ruohotien esittämä orientaatio eli konstruktivistiseen oppimiskäsitykseen perustuva ajattelu, jonka mukaan oppija itse rakentaa oman tietopohjansa kokemuksiin perustuen. Oppiminen on prosessi, jossa yksilö luo uusia merkityksiä sekä itsenäisesti että vuorovaikutuksessa toisten kanssa. Tämä ajattelutapa on noussut erityisesti tietoyhteiskuntatutkimuksessa keskeiseksi ja sillä on paljon yhtymäkohtia kommunikaatio- ja mediatutkimuksen kanssa. Esimerkiksi kysymys siitä, mitä ymmärretään mediatodellisuudella ja miten ihminen konstruoi todellisuuskuvansa on suorastaan keskeinen pyrittäessä ymmärtämään nykyihmisen todellisuuskäsityksiä, arvoja ja mielikuvien merkityksiä.

\section{Erityisen kiinnostava on} luku andragogiikasta, jossa pohditaan sitä, miten aikuisten oppiminen poikkeaa lasten ja nuorten oppimisesta. Esimerkiksi havainto siitä, että aikuinen on oppimisessaan enemmän ongelma- kuin oppiainekeskeinen sopii erinomaisesti elinikäisen oppimisen ja informaatio- ja viestintäteknologian välisten suhteiden pohdintaan, koska informaatioaikakauden keskeinen toimintaedellytys on kyky määritellä ongelma.

\section{Luvussa "kokemuksesta} oppiminen" tarkastellaan erityisesti etäopiskelussa tärkeäksi muodostunutta omakohtaisen kokemuksen osuutta kokonaisvaltaisessa oppimisessa. Siinä myös nojataan amerikkalaisen kasvatus- ja viestintäfilosofi John Deweyn näkemyksiin elämänkokemuksen ja oppimisen välisestä yhteydes- 
tä. Deweyn merkitys on viestinnän ja median kehityksessä vain kasvanut siitä huolimatta, että hänen tuotantonsa tapahtui paljon ennen nykyistä informaation ja tiedon vallankumouksellista kehitystä.

\section{Elinikäisen kasvatuksen} teoreettisiin perusteisiin kuuluu myös luku itseohjautuvuudesta ja itsesäätelystä oppimisessa. Siinä Ruohotie näkee ihmisen aktiivisena tiedon etsijänä, joka itse tekee opiskeluaan koskevia ratkaisuja ja ottaa ensisijaisesti vastuun opiskelunsa tavoitteiden määrittelystä sekä opiskeluprosessin suunnittelusta ja arvioinnista. Samaa asiaa ovat viime vuosien kansainväliset konferenssit korostaneet sanomalla, että tietoyhteiskunnassa vastuu oppimisesta siirtyy yhä enemmän oppijalle itselleen. Kirjassa eritellään erilaisten itseohjautuvuuden ja itsesäätelyn malleja.

\section{Luvussa "uudistava}

oppiminen" Ruohotie pohtii sitä, miten oppiminen muokkaa ihmisiä, minkä jälkeen he ovat erilaisia heidän itsensä ja toisten tunnistamilla tavoilla. Teoreettisina oppi-isinä esitetään Jack Mezirow ja Paulo Freire. Freiren emansipatorinen filosofia on erityisen mielenkiintoinen, koska sillä on ollut vaikutusta laajasti kasvatukseen yleensä ja tietoisuuden kehitykseen. Freiren prosessissa tietoiseksi tulemisesta kaikkein hienostunein tietoisuuden tila on kriittinen tietoisuus. Voidaan ajatella, että kriittisen tietoisuuden saavuttaminen olisi korkeimpia oppimisen saavutettavissa olevia tavoitteita ja hyvin sopiva juuri informaatioajan ihanteeksi.

\section{Kirjansa loppupuolella}

Ruohotie käsittelee oppimista työelämän organisaatioiden yhteyksissä ja esimerkiksi urakehityksessä. Kehittävä vuorovaikutus auttaa yksilöä monimuotoisen uran luomisessa, mika eroaa perinteisestä vertikaalisesta urakehitysmallista. Ruohotie kirjoittaa, että "joustava ura vaatii oman minän ja identiteetin peilaamista, kyseenalaistamista, uudelleenjärjestelyä ja totuttujen rajojen ylittämistä. Kaikki tämä saattaa olla yksinäistä työtä, johon paneudutaan työaikojen ulkopuolella."

\section{Kirjan kolme viimeistä} lukua, "oppiva tiimi", "tiedon luominen organisaatiossa" ja "osaamisen ja muutoksen johtaminen" ovat mielestäni erittäin keskeisiä kaikille työelämässä ja organisaatioissa toimiville. Tampereella on oppivan kaupungin yhteydessä kokeiltu myös "learning cafe"-ajatusta, vapaamuotoista yhdessäoloa oppimisen kannustajana. Noiden kokeilujen tueksi voi nyt jokainen lukea teoreettisia perusteluja oppivan tiimin merkityksestä ja luonteesta.

\section{Käsitellessään uuden} tiedon luomista organisaatiossa Ruohotie liikkuu juuri tällä hetkellä hyvin suositulla tutkimusalueella. Kuten kirjassa todetaan (s.264),§ näkyvän tiedon lisäksi organisaatiossa on runsaasti piilossa olevaa implisiittistä tietoa. Tutkijat erottelevat hiljaisen tiedon (tacit knowledge) ja käsitteellisen tiedon (explicit knowledge). Tätä lukua olisi kenties voinut laajentaa myös siihen suuntaan, mikä olisi yrityksissä luotavan uuden tiedon, innovaatioiden, ja riip- pumattomissa tutkimuslaitoksissa ja yliopistoissa luotavan tiedon luonne. Tosiasia on, että monilla aloilla varsinkin uuden teknologian puitteissa valtaosa uusista innovaatioista tapahtuu joko kokonaan yrityksissä tai yhteistyössä yritysten kanssa. Yritysten tiedon intressi on ollut ainakin perinteisesti välittömän hyödyn saaminen, kun yliopistoissa on sosiologi Mertonin mukaan toteutettu erilaisista intresseistä vapaata, organisoitua skeptisismiä kaiken tiedon suhteen. Nyt informaatioaikakaudella yritysten hyötykin voi olla filosofista viisautta ja luovaa pohdintaa.

\section{Loppuluvussa kirjassa}

tarkastellaan osaamista ja muutoksen johtamista. Siinä yhteydessä pohditaan erityisesti "empowerment"-tavoitetta, joka kirjassa on suomennettu valtuuttamisena tai inhimillisten voimavarojen vapauttamisena, sekä voimaantumisena, yksilön sisäisen voimantunteen korostamisena. Samaa käsitettä on pohtinut tekeillä olevassa tutkimuksessaan Hämeenlinnan opettajankoulutuslaitoksella assistentti Timo Portimojärvi. Hän liittää empowermentin progressiointresseihin, eli muutokseen, eteenpäin pääsemisen ja pyrkimisen sekä pystymisen elämyksiin. Portimojärven mukaan progressiointresseihin kuuluu riskinotto ja uusiin haasteisiin tarttuminen. Riskeissä on kaksi puolta: onnistuminen luo uusia voimaannuttavia kokemuksia, mutta epäonnistumisessa on uhka, joka saattaa nöyryyttävästi palauttaa lähtötilanteeseen.

Ruohotie korostaa myös viestinnän merkitystä nimen- 
omaan johtamiskulttuurin kehittämisessä. Voi perustellusti olettaa, että juuri näiden kysymysten merkitys tulee kasvamaan tulevaisuudessa. Esimerkiksi amerikkalainen Business Week-lehti esittää 2000luvun yritystoiminnan erikoisnumerossaan (August 2128,2000 ), että parinkymmenen vuoden kuluttua yritysjohtajien hallintotapa tulee muuttumaan nykyisestä komento- ja käskemisjärjestelmästä tiimijohtamiseen ja konsensuksen rakentamiseen. Johtajan avuja tulee olemaan erilaisten liittoutumien rakentamiskyky. Lisäksi yritysjohtajien tulee entistä enemmän kyetä globaaliin kommunikoimiseen, löytämään nopeasti vastauksia kysymykseen "kuka tietää?".
Kirja on kokonaisuutena selkeä ja ansiokas esitys koko ammatillisen kasvun ja oppimisen perusproblematiikasta ja perustuu kirjoittajan laajaan kansainväliseen tuotantoon ja osaamiseen alalla. Vähemmälle huomiolle kirjassa jää uuden media- ja informaatioympäristön edellyttämien kommunikaatiotaitojen, kuten digitaalisen lukutaidon ja verkkopedagogiikan esittely, sekä monikulttuurisen maailman haasteet. Tampereen yliopiston ammattikasvatuksen tutkimus- ja koulutuskeskus Hämeenlinnassa jatkanee varmuudella niiden asioiden selvittämistä jatkossa. Englannin kielellä professori Pekka Ruohotie on yhdessä Peter P. Grimmettin kanssa toimittanut jo useita alan kirjoja, joi- den käyttö nyt ilmestyneen suomenkielisen kirjan rinnalla laajentaa tietysti käsiteltävien asioiden piiriä ja näkökulmia. Suomeksi ilmestyneen kirjan käyttöä olisi helpottanut asiahakemisto. Jatkossa tulee tarpeelliseksi myös kehittää englanninkielisen sanaston suomenkielisten merkitysten seurantaa, sillä käsitteiden takana on usein kokonaisen ajattelutavan muuttuminen siirryttäessä virtuaaliyritysten, elektronisen markkinoinnin, globaalin koulutuksen ja immateriaalisten arvojen maailmaan. 